\title{
Forskning og kommunikation
}

Læring og Medier (LOM) - nr. 1, 2008

ISSN 1903-248X

\section{Simon B. Heilesen}

Lektor

Institut for Kommunikation, Virksomhed og

Informationsteknologier, Roskilde Universitscenter

\section{Michael Pedersen}

Konsulent, MPK

CBS Learning Lab, Copenhagen Business School
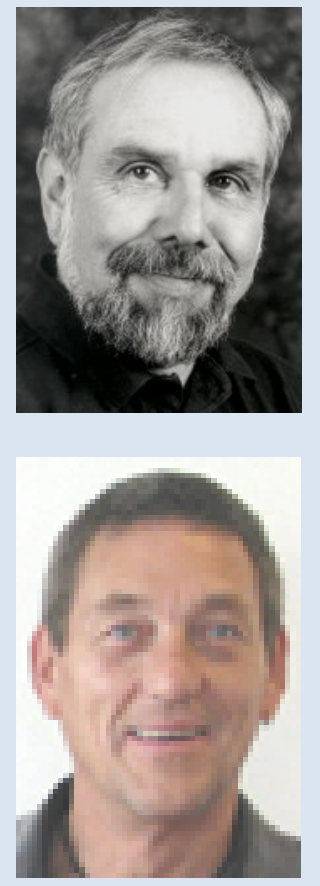

\section{Om temaet: Forskning og kommunikation}

Formidling af videnskabelig viden fylder stadigt mere på de højere uddannelser. Det er blevet en naturlig opgave, og det er i øvrigt også et ufravigeligt krav, at de ansatte skal stille deres viden til rådighed for samfundet, som Lov om Universiteter af 28. maj 2003 slår fast:

- "Universitetet skal som central viden- og kulturbærende institution udveksle viden og kompetencer med det omgivende samfund og tilskynde medarbejderne til at deltage i den offentlige debat."

Det nye tidsskrift Læring og Medier (LOM) er blevet til for at formidle viden om og skabe debat om medieret læring blandt ansatte og studerende på de videregående uddannelser, blandt beslutningstagere og HR-medarbejdere i organisationer og virksomheder, samt i den 
interesserede offentlighed. Det har derfor forekommet naturligt, at tidsskriftets første tema beskæftiger sig med selve den opgave, det er at formidle forskernes viden. Kommunikation om forskning er grundlæggende for udvikling og tilegnelse af viden. Udvekslingen kan antage mange former og forstås ud fra mange synsvinkler. En række spørgsmål om kommunikationens karakter, vilkår og udfoldelsesformer tages op i temanummerets seks artikler. I hovedtræk behandler dette nummer af LOM:

- Fundamentale spørgsmål om samspillet mellem formidler og publikum. Retter formidlingen op på et underskud af viden hos publikum? Eller konstrueres viden i et dialogisk samspil mellem formidler og modtager? Er forskningens resultater en færdigpakket gave til publikum, eller fremkommer de ved gensidige læreprocesser? I sin artikel om den dialogiske drejning inden for forskningskommunikation skitserer Louise Phillips den nyeste tænkning om dialogisk forskningskommunikation, og hun illustrerer den med nogle konkrete eksempler fra et aktuelt forskningsprojekt. Birgitte Ravn Olesen og Christina Hee, som begge er eksperter i aktionsforskning, redegør med udgangspunkt i to forskningsprojekter for denne form for kollaborativ konstruktion af viden, og de vanskeligheder der er forbundet med at gøre op med gængse forestillinger om forskerens rolle.

- Spørgsmål om hvordan forskerens rolle som deltager i den offentlige debat konstrueres, og om hvordan medierne griber forskningsformidling an.

Er det forskningens metoder og resultater som formidles og bliver gjort til genstand for offentlig debat? Eller bliver formidlingen af forskningen skrevet ind i allerede eksisterende politiske agendaer? Både Bente Kristiansen og Ursula Plesner analyserer den massemedierede forskningskommunikation. Bente Kristiansen diskuterer funktionen af forskningsbaseret viden i offentligheden med baggrund af offentlighedsformer og demokratiforståelser. Ursula Plesner analyserer ud fra tre cases, hvad der konkret foregår, når forskellige aktører arbejder sammen om at skabe medietekster med forskningsindhold.

- Spørgsmål om at udnytte medierne, ikke mindst de Nye Medier, optimalt til formidlingen.

Udnyttes de kommunikative potentialer i de nye medier? Eller er der tale om en remediering af de kendte formater? Hvordan skabes situationer, hvor omgivelserne allerede i forskningsprocessens forløb kan indgå i en åben dialog med forskeren og dennes genstandsfelt og dermed blive en aktiv med- og modspiller i skabelsen af resultaterne? Det er nogle af de spørgsmål som Jørgen Bang og Christian Dalsgaard leverer en indsigtsfuld introduktion til gennem deres diskussion af Web 2.0's potentialer for at understøtte videnskonstruktion. Mens Maja Horst reflekterer over betydningen af at give forskningen en rumlig fysisk udfoldelse og invitere omgivelserne til at gå i dialog med forskningsfeltet og derigennem give forskeren mulighed for at fă et aktivt med- og modspil til sine egne iagttagelser og vurderinger.

Tidsskriftet Læring og Medier (LOM) er i sig selv et forsøg med forskningsformidling med vægten lagt især på det sidste af de tre 
ovenstående spørgsmål. Det er hensigten, at det elektroniske tidsskrift ikke alene emnemæssigt skal beskæftige sig bredt med "læring", som forskningsformidling kan siges at være en del af. Det skal også være en platform for at afprøve og diskutere de udtryksformer, som de Nye Medier muliggør. I en tid hvor den danske videnskabelige formidling styres i retning af etablerede og bekvemt målbare publikationsformer, er der grund til at være opmærksom på, at innovative, teknologistøttede måder at samarbejde og formidle på, sammenfattet under den lidt pudsige betegnelse "Science 2.0" har fået godt tag i mange internationale forskningsmiljøer. De Nye Medier inviterer til nye samarbejds- og formidlingsformer, som allerede nu burde være en naturlig del af såvel de videregående uddannelser som forskningsformidlingen. De nye arbejdsformer er imidlertid ikke uproblematiske. Dels gælder som altid, at det er afgørende vigtigt at forstå mediets muligheder. Man skal ikke benytte ny teknologi, blot fordi den er ny. Det helt afgørende for accept er, at den åbner mulighed for at gøre tingene på en bedre måde. Og dels gælder, at gængse begreber om afgrænselighed i tid og rum bliver sat ud af spillet, og dermed udfordres en række konventioner om bl.a. ejerskab, kvalitetskontrol, og meritering.

De høje ambitioner om at stille sig til rådighed for eksperimenter med de nye mediers muligheder indfries måske ikke ganske med dette første temanummer, som i bund og grund er en remediering af det konventionelle, trykte tidsskrift. Artiklerne er skrevet ud fra et "call for papers". De har været igennem et ganske rigoristisk dobbelt blindt peer review, og de er blevet omhyggeligt redigeret som konventionelle tekster, inden de er frosset fast i PDF-format og lagt på nettet i en sammenhæng, der så nogenlunde svarer til det, man kender fra andre tidsskrifter i elektronisk form. Denne form skal der naturligvis også være plads til i den nye formidlingsverden. Den kommer utvivlsomt til at udgøre grundstammen i LOM længe endnu, og den har den store fordel, at formen gør det rimelig nemt på konventionel vis at garantere, at der ikke gives køb på kontrol med bidragenes kvalitet. Men med det nye tidsskrift vil redaktionsgruppen som nævnt også gerne være med til at rokke ved konventionerne for, hvordan forskning og dens resultater kan formidles. Redaktionsgruppen håber således i fremtiden at kunne bringe eksempler på videnskabelig formidling, der i god overensstemmelse med de nye teknologiers karakteristika benytter multimedieproduktioner, Web 2.0 kollaborationsværktøjer, med mere. Og vi tror og håber, at LOM kan være med til at udvikle nyskabende udgivelsesformer, der kan garantere den nødvendige høje videnskabelig kvalitet i utraditionelle og dynamiske formidlingsprodukter.

Velkommen til Læring og Medier!

Michael Pedersen \& Simon Heilesen 